\title{
The Effectiveness of Content-Based Instruction on Beginners' Writing Skills
}

\section{Naoya Shibata \\ Nagoya University of Foreign Studies}

\section{Reference Data:}

Shibata, N. (2019). The effectiveness of content-based instruction on beginners' writing skills. In P. Clements, A. Krause, \& P. Bennett (Eds.), Diversity and inclusion. Tokyo, Japan: JALT.

Content-based instruction (CBI) is "the integration of language teaching aims with content instruction" (Snow, 2014, p. 439). Although CBI has prevailed as one approach to developing a curriculum integrating four language skills in ESL and EFL settings (e.g., Cumming \& Lyster, 2016; Donato, 2016), it is rarely implemented in Japanese secondary educational contexts. Furthermore, although the number of studies on EFL writing in secondary contexts is increasing, research on EFL essay writing in such settings has seldom been conducted in Japan. Therefore, based on data gathered from surveys and essay assignments, this study explored the effects of $\mathrm{CBI}$ on the writing of 105 beginner learners at a private senior high school in central Japan for 9 months. The research findings showed that the participants improved their writing abilities through $\mathrm{CBI}$, regarding the number of tokens used and the increase of supporting sentences.

内容中心教授法は内容指導と言語教育の統合である (Snow, 2014, p. 439)。第2外国語、外国語教育の環境において、同教 授法は4技能を統合する外国語教育カリキュラムとして普及してきているが(例:Cumming \& Lyster, 2016; Donato, 2016)、 日本の中等教育現場ではあまり実施されていない。加えて、中等教育現場での外国語ライテイングの研究は増加してきている が、そのような環境においてのエッセイライテイングの研究は日本ではほとんど行われていない。従って、本研究では, 私学高 等学校に在籍する105名の初学者を対象に、9 月月間アンケートとエッセイ課題を通して、内容中心教授法のライテイング能力 に対しての効果を検証した。結果として、内容中心教授法を通して，学習者たちは使用語数及び補足文の増加においてライテ イング能力を向上させた。

$\mathrm{t}$ is an ultimate aim for ESL/EFL writing teachers to aid learners in utilising writing in order to fulfil learning objectives, including to comprehend specific areas of the subject matter and learn the target language (Hirvela, Hyland, \& Manchon, 2018). This implies that writing teachers can be content-based language teachers. However, many EFL writing instructors "have little knowledge about the theory, research, and pedagogy of EFL writing that affects younger students learning to write in primary and secondary schools" (Lee, 2018, p. 113). Although the number of studies on EFL writing in primary and secondary settings is increasing (e.g., Foster-Sutherland, 2017; Head, 2016), L2 essay writing research in Japanese secondary contexts is scarce.

Essay tasks are currently administered as part of entrance examinations at some universities and sometimes candidates need to write a short report or essay when they apply to a university. Furthermore, a new general university entrance test that includes assessment of writing skills will be introduced in 2020. These changes are leading to a positive washback effect, and recognition of the importance of essay writing instruction has been increasing in Japan. More instruction to help students develop their writing skills needs to be conducted in secondary schools in Japan.

Content-based instruction $(\mathrm{CBI})$ and essay assignments have prevailed in many ESL and EFL teaching contexts (e.g., Cumming \& Lyster, 2016; Donato, 2016). However, in Japanese secondary settings, they have rarely been conducted. Thus, the effect of CBI on Japanese high school students' writing skills has not been researched. In order to explore the influence of $\mathrm{CBI}$ on beginner learners' writing abilities, I conducted this mixed methods study with 105 first-year high school students in central Japan from April to December in the 2017 school year, collecting data from surveys and essay assignments.

\section{Literature Review}

Content-Based Instruction

Content-based instruction (CBI) is "the integration of language teaching aims with content-instruction” (Snow, 2014, p. 439). More specifically, Snow (2017) stated that $\mathrm{CBI}$ is an approach to teaching second and foreign languages in which instructors integrate language and subject matter in class. However, as Brown and Bradford (2017) 
emphasised, the main objective of $\mathrm{CBl}$ is to help learners to develop target language skills, and thus content is a resource to accomplish this.

According to Brinton and Snow (2017), CBI can broadly be divided into three models: theme-based instruction (TBI), sheltered instruction (SI), and adjunct instruction (AI). They define TBI as "instruction that focuses on specific themes of interest and relevance to the learners" (p. 5), SI as instruction in which learners who are improving their target language are divided from L1 speakers and take content instruction delivered in the target language, and $\mathrm{Al}$ as instruction in which a content course instructor and a language course instructor collaborate in order to accomplish both teaching aims.

As $\mathrm{CBI}$ can provide learners with many opportunities to integrate the four language skills-listening, speaking, reading and writing-and conduct collaborative activities (Snow, 2014), learners can also gain many opportunities to develop their writing skills. For example, Donato (2016) compared CBI to traditional teaching methods and reported that learners in the CBI group achieved better results than students in the grammartranslation method group in all types of written tests, including language function, text type suitability, linguistic impact, vocabulary complexity, comprehensibility, and grammatical complexity. Accordingly, CBI seems to be able to play an essential role in developing learners' writing skills in EFL secondary educational contexts. However, this approach to instruction has rarely been conducted or investigated in Japanese EFL secondary contexts; therefore, the effect of $\mathrm{CBI}$ on students' language learning needs to be researched in such settings.

\section{Research Questions}

Based on findings and research issues from the review of the literature, I formed the following two research questions:

RQ1. Do Japanese high school students perceive $\mathrm{CBl}$ as beneficial to their essay writing skills?

RQ2. To what extent do beginner students develop their essay writing skills through $\mathrm{CBI}$ in a Japanese upper secondary context?

\section{Method}

Participants

I conducted the study with a total of 105 first-year high school students (17 males and 88 females) divided into three classes of 35 learners in the Global Course of a Japanese private high school from April to December 2017. At the first class of the school year, introduced the definition of $\mathrm{CBI}$ as well as five-paragraph essays in Japanese and asked the participants to take a survey written in English (see Appendix A). The survey result indicated that all participants had neither taken CBI classes nor written essays before they entered the course. Therefore, I considered all participants as beginners in both CBI and essay writing.

\section{Instruction Procedure}

During the research term, I conducted three 50-minute classes per week based on Brinton and Snow's (2017) TBI model of CBI. The main reading instruction was based on a three-part approach recommended by Lee and VanPatten (2003): prereading, while-reading, and postreading. As part of the postreading stage, I also developed tasks to personalise the content of a text so that learners could "compare the content of the article to previous knowledge" (Lee \& VanPatten, 2003, p. 238). At the beginning of every class, the participants had brainstorming activities to activate their schemata before reading the target topic and talking about it with their classmates. Then, learners skimmed the provided passage to gain basic content. I introduced some key vocabulary in the passage. Afterwards, students read the passage intensively to answer two or three comprehension questions and one discussion question about the content. As the postreading activity, learners talked about the target topic with their classmates to prepare for writing essays, and I provided students with one week to write and revise their drafts at home.

The essay assignments were conducted as a 1-month project. Almost all the participants wrote their drafts and essays and submitted them in paper format and as digital files. In class, the participants exchanged their drafts and wrote comments about the content of their partner's essay during the class. I collected the papers and wrote down, at most, five questions about the content of each essay. Based on the feedback, the participants revised their essays twice. The essays in the data analysis described below were the final versions submitted by the students.

\section{Data Collection}

In this study, I conducted mixed methods research, utilising anonymous surveys about the effect of CBI (see Appendix B) and essay assignments. Regarding the surveys, in order to collect both quantitative and qualitative data and lower the linguistic burden on the participants, 5-point Likert scale survey questions and open-ended questions were created in Japanese and conducted at the beginning, middle, and end of each term. 
The participants wrote academic essays as a 1-month project twice per term, four topics in total: (a) The Relationship Between Blood Types and Personalities, (b) Ways to Popularise Japanese Food in the World, (c) School Uniforms, and (d) Effective Ways to Learn English. All the essays, including drafts, were collected periodically in order to calculate both the quantitative and qualitative development in writing from the perspective of the number of tokens used and the clarity of argument.

\section{Data Analysis}

The quantitative data collected from surveys were analysed and presented as descriptive statistics, and the qualitative data were examined and coded in order to find patterns among the 105 first-year students. Because I had gathered the survey data about the effect of CBI on students' writing abilities in Japanese, I translated the data into English. Similar ideas and comments were categorised into groups.

I evaluated all the essays, including the drafts, from the perspectives of the number of tokens, clarity of content, paragraph construction, and communicability, which I defined as the ability to avoid making grammatical errors and mistakes that hinder readers from understanding the intended meaning. The mean number of tokens used was calculated to reveal the quantitative development; the qualitative development was assigned codes, such as examples and reasons; and similar development was categorised into groups. Due to space limitations, it is not possible to introduce many essay excerpts; therefore, I tracked one student's writing, chosen at random, in order to provide a consistent example.

\section{Results}

Students' Beliefs About the Usefulness of CBI to Develop Their Writing Skills

Data collected in the class surveys indicated that students' understanding of and feelings about CBI changed over time. At the beginning of the school year, about $70 \%$ of the participants had negative impressions of $\mathrm{CBI}$ and only $20 \%$ gave positive answers. On the other hand, they changed their beliefs about the effectiveness of the curriculum starting in May and gradually developed more positive feelings. As a result, at the end of the research term, about $60 \%$ of the participants reported finding CBI useful to develop their writing skills (see Table 1). However, it is essential to remember that about $35 \%$ of the learners still had neutral ideas about the usefulness of $\mathrm{CBI}$ at the end of the research term.
Table 1. Students' Beliefs About the Usefulness of CBI to Develop Their Writing Skills $(N=105)$

\begin{tabular}{lccccc}
\hline & \multicolumn{5}{c}{ No. of responses } \\
\cline { 2 - 6 } Month & Definitely no & No & So-so & Yes & Absolutely yes \\
\hline April 2017 & 16 & 56 & 14 & 14 & 5 \\
May & 3 & 22 & 67 & 6 & 7 \\
July & 1 & 10 & 70 & 17 & 7 \\
September & 1 & 4 & 42 & 44 & 14 \\
October & 3 & 5 & 30 & 51 & 16 \\
December & 1 & 5 & 37 & 41 & 21 \\
\hline
\end{tabular}

Note. Surveys conducted from April to December 2017. Q1: Do you think CBI is beneficial to develop your writing skills?

According to the open-ended questions, those who had negative feelings about $\mathrm{CBI}$ commented that they had difficulty in understanding the content of the classes conducted only in English as they had previously only taken English classes through the grammar-translation method. Therefore, they did not think CBI would be useful to develop their English skills, including writing skills. For example, in April, one student stated,

Although the teacher tries to speak English very slowly and use easy expressions during the class, I cannot understand his instruction and the subject matters. So, I do not think that I will improve my language skills especially writing skill from this curriculum. I want to take English classes while checking the Japanese translation of each English sentence and the grammar. (Anonymous, survey, April 2017)

However, starting in May, the number of students who commented that focusing on content and meaning helped them to understand the subject matter and learn how to write in English increased. In addition, most students who perceived CBI positively emphasised the importance of doing communicative activities about the content with their classmates. For example,

I am not sure if I develop my grammatical accuracy and complexity through content-focused classes, but talking with my classmates about the class conten helped me to deepen my comprehension about the assigned topics. And I was also 
able to broaden my ideas and learn some useful expressions from them. When 1 wrote essays, I tried to argue the ideas with examples and reasons and use the words and idioms I learnt from my classmates to improve the content of my essay and avoid repeating the same words. (Anonymous, survey, May 2017)

Many similar comments were found during the rest of the research term. However, although the participants found content-based interactive activities beneficial to deepen their understanding about the assigned topics and widen their vocabulary knowledge, they did not think that they improved their grammatical accuracy and complexity through the activities.

More than half of the students mentioned that CBI with essay assignments provided them with many opportunities to reflect upon their experiences and review the subject matter, which aided them in deepening their comprehension of the specific area of the assignment.

I think focusing on content and meaning in class and writing essays about the topic are helpful to develop my language skills, including writing abilities, and better understand the subject matter because I did not pay too much attention to grammatical accuracy and had many opportunities to reflect on my experiences related to the topic. (Anonymous, survey, December 2017)

Accordingly, CBI was perceived by students to have played a significant role in helping them to both develop their writing skills and deepen their understanding of the subject matter.

\section{Students' Learning Outcomes From CBI}

Data taken from samples of students' writing showed that their writing improved in both quality and quality over the term of this study. Over time, the length of the student's essays increased. All the participants increased the number of tokens used to write five-paragraph essays, regardless of the assigned topic (see Table 2). Furthermore, as time passed, the standard deviation also increased, which may indicate the different developmental speed of slower and faster learners, topic familiarity, and differences in their motivation.
Table 2. The Number of Tokens Used in Student Essays $(N=105)$

\begin{tabular}{|c|c|c|c|c|}
\hline \multirow[t]{3}{*}{ Measure } & \multicolumn{4}{|c|}{ Term } \\
\hline & \multicolumn{2}{|c|}{$1 \mathrm{st}$} & \multicolumn{2}{|c|}{$2 \mathrm{nd}$} \\
\hline & April-May & June-July & Sept.-Oct. & Nov.-Dec. \\
\hline Topic & $\begin{array}{c}\text { Blood type and } \\
\text { personality }\end{array}$ & Japanese food & $\begin{array}{c}\text { School } \\
\text { uniforms }\end{array}$ & $\begin{array}{c}\text { Ways to study } \\
\text { English }\end{array}$ \\
\hline Mean & 179.6 & 225.1 & 272.7 & 331.2 \\
\hline SD & 29.4 & 36.2 & 31.3 & 37.0 \\
\hline Low-high & $150-265$ & $189-365$ & 209-391 & $300-461$ \\
\hline
\end{tabular}

Note. Essay assignments conducted during the 2017 school year.

Regarding the qualitative development, examination showed that although all the participants tended to utilise first-person pronouns, such as $I$ and we, they tried to reflect upon their experiences and compare them with the subject matter throughout the research term. Consequently, as students gained more writing experience and were instructed through $\mathrm{CBI}$, they sought to provide reasons and examples clearly and sometimes referred to secondary sources in order to support their ideas and opinions as objectively as possible.

When the students wrote about the first two topics, although an increase in the number of tokens was found, most had difficulty in arguing and supporting their ideas logically. For example, in April Student A wrote,

That example is my sister. Her blood type is B and her personality is "serious" and "modest." Usually, a blood type B's personality is told that he or she is "cheerful" and "tolerant." However, my sister is always mistaken with blood type A because she is serious. (Student A, draft, April 2017)

However, after taking CBI classes for one month, the learner revised the paper and wrote,

The reason is that $\mathrm{I}$ have a familiar example. That example is my sister. Her blood type is B and her personality is "serious" and "modest." Usually, a blood type B's personality is told that he or she is "cheerful" and "tolerant." My sister is always mistaken with blood type A. A common personality for blood type A is "serious" and "sincere." Comparing the personality of blood type B and A, my sister's personality 
is more like A. Examining my sister's pattern made me think that blood type has nothing to do with personality. (Student A, essay, May 2017)

Although the student developed the paragraph by providing more information, the logic was still weak. A similar pattern emerged in the writing of other participants during the first term; each paragraph tended to be short and a difficulty in utilising discourse markers could be found, resulting in lack of content depth.

On the other hand, the essays about the topics conducted during the second term indicated deeper insight into the topics and more reflection on their personal experiences. The participants provided more examples and organised their arguments more logically, even though the common factor of increasing length of the essay and improving the logic was adding personal experiences. For example, in November, as a draft, Student A wrote,

First, watching English movies is good way to increase English vocabulary and improve listening skill. The good way to meet a lot of new words is watching English movies. If I write down new words, I can also train writing skills. Therefore, watching movie is good for increasing English vocabulary and improve listening skill. (Student A, draft, November 2017)

Although the logical development can be seen comparing the beginning and the end of the term even in the drafting stage, the draft about ways to learn English written in November lacked information to support the argument. In December, the student revised the paper by reflecting upon their own learning methods more deeply.

First, watching English movies is a good way to increase English vocabulary and improve listening skill. If I do not know enough English vocabulary, I cannot do anything, so vocabulary is essential. If I do not meet words which I do not know, I cannot get the opportunity to know new words. The good way to meet a lot of new words is watching English movies. I can listen to English a lot while watching English movies, so I can train listening skills. Moreover, if I write down new words, I can also train writing skills. Moreover, after watching movies, I look up new words and memorize the words. Therefore, watching movie is good for increasing English vocabulary and improve listening skill. (Student A, essay, December 2017)

A similar development was indicated in other students' papers during the second term; the students used more words by utilising discourse markers and providing more reasons and examples in order to support their arguments logically, compared to the first term.

\section{Discussion}

The first research question was whether high school students in Japan would perceive $\mathrm{CBI}$ as beneficial to their essay writing skills. Although many of the participants found it challenging to develop their writing abilities through $\mathrm{CBI}$ at the beginning of the research term, the number of positive comments gradually increased (Table 1). However although students commented that they were able to deepen their knowledge of assigned topics through authentic interactive activities and sought to develop the content quality of their essays, they did not find CBI helpful to improve their grammatical accuracy and complexity in writing. This supports Lightbown's (2014) assertion that CBI encourages learners to use the target language for authentic communication while also paying attention to topics and Lyster's (1999) finding that this approach does not always contribute to development of accuracy and complexity.

More importantly, the participants reported that CBI played a significant role in activating their writing development and comprehension of the topics. This finding supports the notion that learners should eventually conduct writing activities "not just to demonstrate what they have learned through a written product, but also to maximise their learning through the resources that writing provides" (Hirvela et al., 2018, p. 53).

The second research question was to explore to what extent CBI helped the participants to develop their essay writing skills. The results indicated that CBI positively influenced their writing skills quantitatively: The number of words used increased (see Table 2). The mean number of words used in the first essay assignment was about 180 ; in the last essay it was about 330 words. Even the student who used the lowest number of words, 150 in the first essay, doubled the number of words by the end of the research term. Furthermore, by reflecting upon their personal experiences and comparing them with the topic content, the learners conveyed and supported their arguments. However, as Lightbown (2014) stated, "Success in understanding academic content is no guarantee that students' L2 proficiency will continue to develop toward greater accuracy, sophistication, and appropriate use" (p. 126). A noticeable development in accuracy and appropriate use of words was not revealed even though the participants in this present study continued to develop the content quality throughout the research term.

\section{Conclusion and Limitations}

The overall survey data and essays indicated that CBI was beneficial to develop the learners' writing skills, especially in increasing the number of words used and in providing more examples and reasons. CBI also provided the participants with many 
opportunities to reflect upon their personal experiences and compare them. However, although the participants also found it useful to take part in content- and meaningfocused activities, they did not improve their grammatical accuracy and complexity.

As to the limitations of this study, the methods used to collect and analyse data should be reconsidered. This investigation was administered for only 9 months, and all the data needed to be collected and analysed in a limited amount of time. Furthermore, in order to calculate the effect of CBI on writing abilities, more critical discourse analysis should be implemented. In the analysis, the participants did not seem to show improvement in their writing complexity; however, more critical discourse analysis may reveal some development from other perspectives, including in frequency of words and in grammar structures used. Although I measured the quantity of words in the drafts and the final products, I did not analyse the quality of the words used, for example from the perspective of word frequency. Therefore, in order to reveal how each draft differs regarding the complexity of the words used, the Lexical Frequency Profile, developed by Laufer and Nation (1995), might be an effective tool.

This research was conducted in order to reveal the usefulness of CBI in improving beginner learners' essay writing abilities in a Japanese upper secondary school setting. In this specific set of circumstances, the research findings indicated a positive influence on students' writing skills quantitatively. These research results will hopefully be beneficial for secondary school teachers considering implementing $\mathrm{CBI}$ in their own teaching contexts.

\section{Bio Data}

Naoya Shibata is a part-time lecturer at Nagoya University of Foreign Studies, where he acquired an MA in TESOL. He is also a doctoral student in the EdD in TESOL program at Anaheim University. His research interests include second language writing, contentbased instruction, and language testing.

\section{References}

Brinton, D. M., \& Show, M. A. (2017). The evolving architecture of content-based instruction. In M. A. Snow \& D. M. Brinton (Eds.), The content-based classroom: New perspectives on integrating language and content (2nd ed., pp. 2-20). Ann Arbor: University of Michigan Press.
Brown, H., \& Bradford, A. (2017). EMI, CLIL, \& CBI: Differing approaches and goals. In P. Clements, A. Krause, \& H. Brown (Eds.), Transformation in language education (pp. 328-334). Tokyo, Japan: JALT. Retrieved from: https://jalt-publications.org/files/pdf-article/jalt2016pcp-042.pdf

Cumming, J., \& Lyster, R. (2016). Integrating CBI into high school foreign language classrooms. In L. Cammarata (Ed.), Content-based foreign language teaching: Curriculum and pedagogy for developing advanced thinking and literacy skills (pp. 77-97). New York, NY: Routledge.

Donato, R. (2016). Sociocultural theory and content-based foreign language instruction: Theoretical insights on the challenge of integration. In L. Cammarata (Ed.), Content-based foreign language teaching: Curriculum and pedagogy for developing advanced thinking and literacy skills (pp. 25-50). New York, NY: Routledge.

Foster-Sutherland, J. C. (2017). Combining cross-cultural understanding and academic writing. In P. Clements, A. Krause, \& H. Brown (Eds.), Transformation in language education (pp. 348-354) Tokyo, Japan: JALT. Retrieved from: https://jalt-publications.org/files/pdf-article/jalt2016pcp-045.pdf

Head, P. (2016). Introducing freewriting to a Japanese high school English class. In P. Clements, A. Krause, \& H. Brown (Eds.), Focus on the learner (pp. 90-98). Tokyo, Japan: JALT. Retrieved from http://jalt-publications.org/sites/default/files/pdf-article/jalt2015-pcp_013.pdf

Hirvela, A., Hyland, K., \& Manchon, R. M. (2018). Dimensions in L2 writing theory and research: Learning to write and writing to learn. In R. M. Manchon \& P. K. Matsuda (Eds.), Handbook of second and foreign language writing (pp. 45-63). Berlin, Germany: Walter de Gruyter.

Laufer, B., \& Nation, P. (1995). Vocabulary size and use: Lexical richness in L2 written production. Applied Linguistics, 16(3), 307-322. https://doi.org/10.1093/applin/16.3.307

Lee, I. (2018). EFL writing in schools. In R. M. Manchon, \& P. K. Matsuda (Eds.), Handbook of second and foreign language writing (pp. 113-139). Berlin, Germany: Walter de Gruyter.

Lee, J. F., \& VanPatten, B. (2003). Making communicative language teaching happen (2nd ed.). New York, NY: McGraw Hill.

Lightbown, P. M. (2014). Focus on content-based language teaching. Oxford, England: Oxford University Press.

Lyster, R. (1999). Immersion. In B. Spolsky (Ed.), Concise encyclopaedia of educational linguistics (pp 626-632). Oxford, England: Pergamon.

Snow, M. A. (2014). Content-based and immersion models of second/foreign language teaching. In M. Celse-Murcia, D. M Brinton, \& M. A. Snow (Eds.), Teaching English as a second or foreign language (4th ed., pp. 438-454). Boson, MA: National Geographic Learning/Heinle Cengage.

Snow, M. A. (2017). Content-based language teaching and academic language development. In E. Hinkel (Ed.), Handbook of research in second language teaching and learning (pp. 159-172). New York, NY: Routledge. 
Appendix A

Survey Conducted at the Beginning of the Research Term

Learners' Background

Introduction:

- This is a questionnaire about you.

- This information will help me to guide you to improve your writing skills.

- This information is important because I may change my teaching approach to help you better.

- You need not complete this questionnaire if you do not want to. Please feel free to hand it in blank.

- These questions have nothing to do with your grades, so please answer them sincerely.

- If you have any questions, please put up your hand and ask me.

- I sincerely appreciate your answer.

Instructions:

- $\quad$ Please try to answer every question. Think carefully about your answers.

- Please do not write your name or your student number on this paper.

Please tell me about you briefly.

1. How long have you studied English?

A: 4 years B: $5-8$ years C: $9-10$ years D: more than 10 years

2. Which English qualification do you have? Please circle all that apply to you.

STEP EIKEN: 5, 4, 3, pre-2, 2, pre-1, 1

TOEIC: TOEFL: Other:

3. Have you ever studied abroad?

$$
\text { Yes (country: how long in total: year(s) / month(s)/week(s)) }
$$$$
\text { No }
$$

4. Have you ever taken content-based instruction? Yes / No

5. Have you ever written academic essays? Yes / No
Appendix B

Survey Conducted Periodically During the Research Term

ライティング/スピーキング能力向上のための活動の有効性についてのアンケート

Instruction

1)このアンケートは授業及び課題として行っている活動がどのように皆さんのライティング能力向上

に役立つているかを知るためのものです。

(2)このアンケートは皆さんの評価には一切関係ありません。

(3)自由回答も含め、全ての質問に答えてください。

Q1: Content-Based Instruction(内容中心教授法:文法事項ではなく意味内容に重点を置いた授業 活動) は自身のライティング能力向上に役立っていると感じますか?

\begin{tabular}{|l|l|l|l|l|}
\hline かなりそう感じる & そう感じる & どちらともいえない & あまり感じない & 全く感じない \\
\hline & \multicolumn{3}{|l|}{} \\
\hline
\end{tabular}

をできる限り具体的に教えてください。

Q3: Brain Storming活動は自身のライティング・スピーキング能力向上に役立っていると感じます か?

\begin{tabular}{|l|l|l|l|l|}
\hline かなりそう感じる & そう感じる & ぞちらともいえない & あまり感じない & 全く感じない \\
\hline & & & & \\
\hline
\end{tabular}

Q4: 自身のライティング・スピーキング能力向上のためにBrain Storming活動がどのように役立った・ 役に立たなかったかをできる限り具体的に教えてください。

Q5: 授業内で行っている教科書内容に関するトピックでのTimed-Conversation及びSmall-Talkは自 身のライティング・スピーキング能力向上に役立っていると感じますか?

\begin{tabular}{|l|l|l|l|l|}
\hline かなりそう感じる & そう感じる & ぞちらともいえない & あまり感じない & 全く感じない \\
\hline & & & & \\
\hline
\end{tabular}

Q6: 自身の質的ライティング能力向上のためにTimed-Conversation及びSmall-Talkがどのように役 立った・役に立たなかったかをできる限り具体的に教えてください。 
Q7: 約1力月程かけて行う教科書内容に関連したトピックに関するエッセイ課題は自身のライテイン グ能力に役立っていると感じますか?

\begin{tabular}{|l|l|l|l|l|}
\hline かなりそう感じる & そう感じる & どちらともいえない & あまり感じない & 全く感じない \\
\hline & & & & \\
\hline
\end{tabular}

Q8: 自身のライティング能力向上のために約1力月程かけて行う教科書内容に関連したトピックに

関するエッセイ課題がどのように役立った・役に立たなかったかをできる限り具体的に教えてくださ

い。

Q9:自身のスピーキング能力が向上するにしたがってライティング能力が向上しているように感じま すか?(または、自身のライティング能力が向上するにしたがってスピーキング能力が向上している ように感じますか?)

\begin{tabular}{|l|l|l|l|l|}
\hline かなりそう感じる & そう感じる & ぞちらともいえない & あまり感じない & 全く感じない \\
\hline & & & & \\
\hline
\end{tabular}

Q10: Q9で答えた理由についてできる限り具体的に教えて下さい。

アンケートは以上です。ありがとうございました。 